DOI: https://doi.org/10.35387/ucj.2(4).2021.83-92

NINA HOMELIA

\title{
OVERVIEW OF THE MAIN 2021 MASS EVENTS HOLDING BY UNESCO CHAIR ON LIFELONG PROFESSIONAL EDUCATION IN THE XXI CENTURY
}

\begin{abstract}
The article highlights the main mass events of 2021, holding by the initiative of UNESCO Chair on Lifelong Professional Education in the XXI Century based on Ivan Ziaziun Institute of Pedagogical Education and Adult Education of National Academy of Educational Sciences of Ukraine. Among the main mass events of 2021 in the article are the following: annual webinar «Mother Language and Multilingual Education in the Context of Sustainable Development - 2021»; annual Internet seminar «Development of Comparative Professional Pedagogy in the Context of Globalization and Integration Processes»; webinar "Civic and patriotic ideas of Taras Shevchenko in the socio-cultural and educational space of Ukraine 2021»; IX scientific-practical conference «Museum pedagogy - problems, nowadays, prospects»; XIX International Art and Pedagogical Readings in Memory of Professor Oksana Rudnytska «Lifelong Pedagogical Education in the XXI Century: experience, innovations, trends»; All-Ukrainian scientific-practical conference with international participation «Psychological Support of the Elderly in Pandemic Period». The main thematic directions of mass events, their purpose and venue are determined. The role of each event for individual listeners and society as a whole is shown. It was found that UNESCO Chair on Lifelong Professional Education in the XXI Century carries out organizational, cultural, educational, research, scientific, design, publishing, information activities in accordance with the purpose of the Chair.
\end{abstract}

Key words: overview, mass events, webinars, conference, Internet seminar, UNESCO Chair.

\section{ОГЛЯД ОСНОВНИХ МАСОВИХ ЗАХОДІВ 2021 РОКУ, ЩО ВІДБУЛИСЯ 3 ІНІЦІАТИВИ КАФЕДРИ ЮНЕСКО «НЕПЕРЕРВНА ПРОФЕСІЙНА ОСВІТА ХХІ СТОЛІТТЯ»}

Анотація. У статті висвітлено основні масові заходи 2021 року, що відбулися з ініціативи Кафедри ЮНЕСКО «Неперервна професійна освіта ХХІ століття» Інституту педагогічної освіти $і$ освіти дорослих імені Івана Зязюна Національної академії педагогічних наук України. Серед головних масових заходів 2021 року у статті виокремлено такі: щорічний вебінар «Рідномовна і багатомовна освіта у контексті сталого розвитку суспільства - 2021»; щорічний Інтернет-семінар «Розвиток порівняльної професійної педагогіки у контексті глобалізаційних та інтеграційних процесів 2021»; щорічний вебінар webinar «Громадянсько-патріотичні ідеї Тараса Григоровича Шевченка в соціокультурному та освітньому просторі України - 2021»; IХ науково-практична конференція «Музейна педагогіка - проблеми, сьогодення, перспективи - 2021»; ХІХ Міжнародні мистецькопедагогічні читання пам'яті професора Оксани Петрівни Рудницької «Неперервна педагогічна освіта ХХІ століття: досвід, інновації, тенденцї̈; Всеукраїнська науково-практична конференція з міжнародною участю «Психологічна підтримка літніх осіб в період карантину». Визначено основні тематичні напрями масових заходів, їх мету й місце проведення. Показано роль кожного заходу для окремих слухачів та суспільства в цілому. Виявлено, що Кафедра ЮНЕСКО «Неперервна професійна освіти ХХІ століття» здійснює організаційну, культурно-освітню, науково-дослідницьку, наукову, проєктну, видавничу, інформаційну діяльності відповідно до мети кафедри. ЮНЕСКО.

Ключові слова: огляд, масові заходи, вебінари, конференція, інтернет-семінар, Кафедра

Introduction. In 2021, UNESCO Chair on Lifelong Professional Education in the XXI Century, based on Ivan Ziaziun Institute of Pedagogical Education and Adult Education of National Academy of Educational Sciences of Ukraine actively implemented one of the main tasks of UNESCO Chair to promote networking for the exchange of knowledge and best practices, through the organization of mass events, the creation of a database and a dedicated website, and the preparation and dissemination of publications, including online.

In accordance with the strategic goals of the UNESCO Medium-Term Strategy Program - 2014-2021 (General Conference Resolution $37 \mathrm{C} / 4$ ), the priorities UNESCO Chair activities are consistent with the Major Programs I «Education»; III «Social Sciences and Humanities» and "Culture». Accordingly, the main areas of activity of these programs are: I - 
«Member States' support for the achievement of the Sustainable Development Goals 4 (SDG) - «Education 2030»; III - «Promoting intercultural dialogue and involving young people in building peaceful and open societies» and IV «Culture»-«Encouraging creativity and diversity of cultural expressions, as well as safeguarding intangible cultural heritage for the sake of ensuring sustainable development». The activity of the UNESCO Chair is directed on strengthening role of adult education as an important factor of social progress, competitiveness of the state, creation of conditions for self-development and self-realization of the individual in the context of the concept «lifelong education». That is why according to strategic goals of the UNESCO Medium-Term Strategy Program UNESCO Chair UNESCO annually holds interesting and modern mass events in the field of education, culture and innovation (Sotska, 2020).

Theoretical basis and research methods. In covering the review of the main mass events of UNESCO Chair in 2021, we relied on open sources, including: official websites of institutions, official pages of institutions on social networks, publications in newspapers and scientific journals. Documentary and legislative materials were also used. In the process of information research of the publication we used general scientific research methods, such as theoretical methods (generalization and systematization).

The aim of the study to overview of the main 2021 mass events holding by UNESCO Chair on Lifelong Professional Education in the XXI Century

Results. We propose to review only the main and most important mass events that were held by the initiative of UNESCO Chair on Lifelong Professional Education in the XXI Century in 2021.

MOTHER LANGUAGE AND MULTILINGUAL EDUCATION IN THE CONTEXT OF SUSTAINABLE DEVELOPMENT. In the era of globalization, most countries are at different stages of cultural and multiculturalism, which involves the implementation of the ideas of humanization, national identity, mutual understanding and tolerance of different cultures, religions, languages, cultural heritage.

The key event that focused on the problems of native and multilingual education was the proclamation of the International Mother Lan- guage Day on February 21 at the 1999 UNESCO General Conference. This event recognizes the importance of preserving cultural and linguistic diversity in the context of sustainable development, so the organization focuses on preserving cultural and linguistic differences that promote tolerance and respect for other languages.

In order to ensure the outlined priority of multilingual and native language education in Ukraine, UNESCO Chair on Lifelong Professional Education in the XXI Century and Ivan Ziaziun Institute of Pedagogical Education and Adult Education of NAES of Ukraine initiated annual webinars «Mother Language and Multilingual Education in the Context of Sustainable Development» (Vovk \& Kotun, 2021).

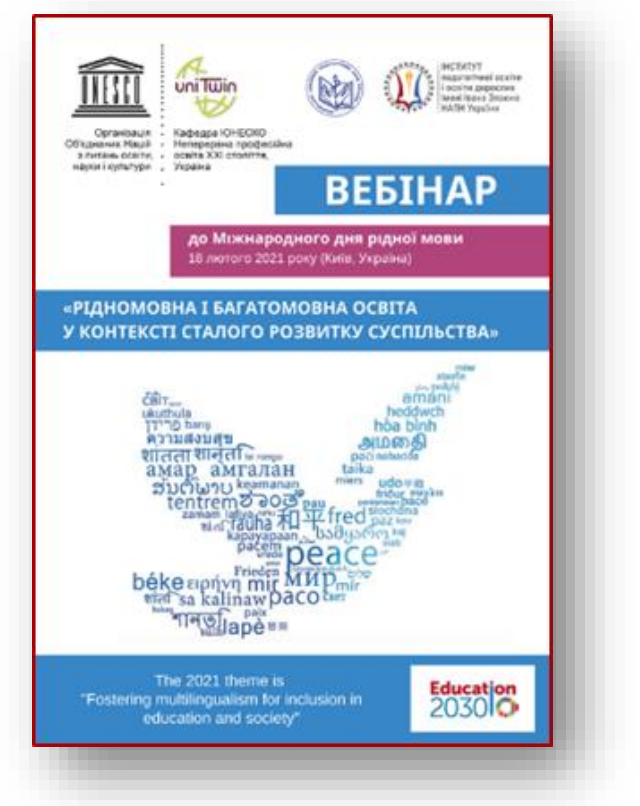

On February 18, 2021, the annual webinar «Mother Language and Multilingual Education in the Context of Sustainable Development 2021» dedicated to the International Mother Language Day was held. The main initiator of the event was UNESCO Chair. The following educational institutions co-organized the webinar: Taras Shevchenko Institute of Literature of National Academy of Sciences of Ukraine; Taras Shevchenko All-Ukrainian Society «Prosvita»; Anton Makarenko Sumy State Pedagogical University; V.G. Korolenko Poltava National Pedagogical University; Anton Makarenko Kyiv Professional and Pedagogical College; Gymnasium-boarding School №13 in Kyiv. The theme of the International Mother Language Day 2021 is «Promoting the devel- 
opment of multilingualism for inclusion in education and society». UNESCO recognizes that languages and multilingualism can promote inclusion in the educational environment, and the Sustainable Development Goals focus on ensuring that all ethnic groups develop in educational, cultural and social contexts. More than 50 participants were on the webinar (public figures, scientists, teachers, students, post graduates, university professors, teachers of secondary and preschool institutions, trainers).



Fig. 1. Participants of «Mother Language and Multilingual Education in the Context of Sustainable Development - 2021» webinar

During the discussion platform, wellknown Ukrainian scientists revealed the current priorities for the development of mother language education on the basis of national values, which found a solution in discussing such issues as: Language - a cosmic phenomenon (speaker - Movchan Pavlo - Chairman of the Taras Shevchenko All-Ukrainian Society «Prosvita»); Mission of the Ukrainian language in the European multilingual space (speaker Filipchuk Heorhii - Doctor of Sciences, Professor, Full Member of the National Academy of Educational Sciences of Ukraine); A. Krymskyi - orientalist, political scientist and Ukrainian linguist - patriot (up to 150 years from the date of birth) (speaker - Halchenko Serhii PhD in Philology, Deputy Director of the Taras Shevchenko Institute of Literature of the National Academy of Sciences of Ukraine); Possibilities of using Ukrainian literature composition in mother language lessons (speaker Yushchuk Ivan - Professor, the Head of the Department of Slavic Philology and General Linguistics, Kyiv International University).

Ukrainian scientists, teachers presented valuable achievements of educational practice in the development of mother language learning in educational institutions of various types: Linguistic family studies (educational potential of linguistic culture of the native land) (speaker - Semenog Olena - Doctor of Sciences, Professor, Head of the Department of Ukrainian Language and Literature, Anton Makarenko Sumy State Pedagogical University); Virtual tour of the multimedia dictionary (speaker - Nadutenko Margarita - PhD, researcher at the Department of Linguistics of the Ukrainian Language and Information Fund, National Academy of Sciences of Ukraine, the Head of the All-Ukrainian Center for Vocabulary); Development of teacher's professionalism on the basis of creative and scientific cooperation (speaker - Khodatska Olha - Methodist of the boarding school № 13 in Kyiv); Development of mother language teaching traditions at Anton Makarenko Kyiv Professional and Pedagogical College (speaker - Bronnikova Valentyna - PhD, teacher of Anton Makarenko Kyiv Professional and Pedagogical College, teacher-methodologist).

The Program of «Mother Language and Multilingual Education in the Context of Sustainable Development - 2021» webinar can be download by the link https://cutt.ly/GUEHmqU

DEVELOPMENT OF COMPARATIVE PROFESSIONAL PEDAGOGY IN THE CONTEXT OF GLOBALIZATION AND INTEGRATION PROCESSES. In 2011 on the basis of the Agreement on Cooperation between the Ivan Ziaziun Institute of Pedagogical Education and Adult Education of NAES of Ukraine and Khmelnytskyi National University, was established the Center of Comparative Professional Pedagogy to find ways to provide scientific and methodological support implementation of scientific comparative and pedagogical research and their implementation in the practice of different levels educational institutions.

In order to involve native and foreign researchers in the discussion of the methodology of comparative research, the conditions of their effectiveness and efficiency on the basis of the Center has been conducting International Scientific and Methodological Seminar «Development of comparative professional pedagogy in the context of globalization and integration processes» for 10 years. UNESCO Chair on Lifelong Professional Education in the XXI Century is a co-organizer of the Seminar almost 5 years. The seminar is a cyclical event that since 2012 has served as an effective platform for sharing the results of scien- 
tific research and discussing them in a comparative dimension. Its purpose is to promote the development of comparative professional pedagogy as a scientific field and discipline in Ukraine, as representatives of higher education in Ukraine and abroad, including Great Britain, Poland, Germany, USA, Canada, China and others, are regularly involved in the international seminar.

During the years of the seminar, scientific and scientific-pedagogical workers considered topical issues in the following areas:

1. Features of development and implementation of joint curricula of higher education institutions in the formation of the European educational space.

2. Organizational and pedagogical principles of professional training: comparative aspect.

3. Improving foreign language training of scientific and pedagogical staff in the context of European guidelines.

4. Trends in professional development of specialists in the world educational space.

5. Modern pedagogical innovations in educational systems of different countries.

6. Social partnership as a joint responsibility of the state and the community for the quality of professional education and adult education.

7. New forms of professional development of scientific and pedagogical workers in the conditions of European educational space formation.

8. Introduction of foreign experience progressive ideas on the methods of teaching a foreign language in the context of the New Ukrainian school formation and development.

9. Strategies of intercultural communication in education.

10. Ensuring the quality of teaching staff professional training in foreign countries.

11. Modern approaches to teaching foreign languages and cultures.

12. Comparative professional pedagogy and cross-cultural dialogues.

13. Methods of democratic adult education in the world educational space.

14. Teaching staff for adult education: training and professional development in foreign countries.

To implement national restrictive measures due to the epidemiological situation, and taking into account the recommendations of international organizations, including UNESCO and the Organization for Economic Cooperation and Development, on the implementation of educational and scientific activities of educational institutions in distance learning, 2020 and 2021. The Internet seminar was chosen as the form of the event.

In 2021, the topic of the Internet seminar was formed within the research of the Department of Foreign Systems of Pedagogical Education and Adult Education (Ivan Ziaziun Institute of Pedagogical Education and Adult Education of the National Academy of Educational Sciences of Ukraine) «Theory and practice of pedagogical education quality assurance in foreign countries» (2020-2022). Key reports of the 2021 Internet seminar were:

Accreditation as an effective mechanism for ensuring the quality of higher pedagogical education: the international dimension (speaker - Natalia Avsheniuk - Doctor of Sciences, Head of the Department of Foreign Systems of Pedagogical Education and Adult Education, Member of the National Agency for Higher Education Quality Assurance (Ukraine)); Modern mechanisms for ensuring the pedagogical education quality and quality control in the US (speaker - Yaroslav Pylynskyi, PhD, Leading Researcher of the Department of Foreign Systems of Pedagogical Education and Adult Education); Features of Teacher Training Quality Assurance in Germany (speaker - Liudmyla Diachenko, PhD, Senior Researcher, of the Department of Foreign Systems of Pedagogical Education and Adult Education); Quality Assurance in Austrian Higher Education Institutions (speaker - Marianna Marusynets, PhD, Senior Researcher of the Department of Foreign Systems of Pedagogical Education and Adult Education); Monitoring the Quality of Higher Education: Hungary's Experience (speaker - Kateryna Hodlevska, PhD, Senior Researcher of the Department of Foreign Systems of Pedagogical Education and Adult Education); Problems and Challenges of Higher Education Quality Assurance in Turkey (speaker - Nadiia Postryhach, Doctor of Sciences, Senior Researcher of the Department of Foreign Systems of Pedagogical Education and Adult Education); Development of various types of speech communication activities in online learning (speaker - Kateryna Skyba, Doctor of Sciences, Professor of the Department of German Philology and Translation 
Studies, Khmelnytskyi National University). Based on the results of the seminar, a collection of abstracts is published annually.

Participants of the seminar have the opportunity to cover current issues of native and foreign education in the scientific journal «Comparative Professional Pedagogy» https://cutt.ly/aUEZV2B .

CIVIL AND PATRIOTIC IDEAS OF TARAS SHEVCHENKO IN THE SOCIO-CULTURAL AND EDUCATIONAL SPACE OF UKRAINE

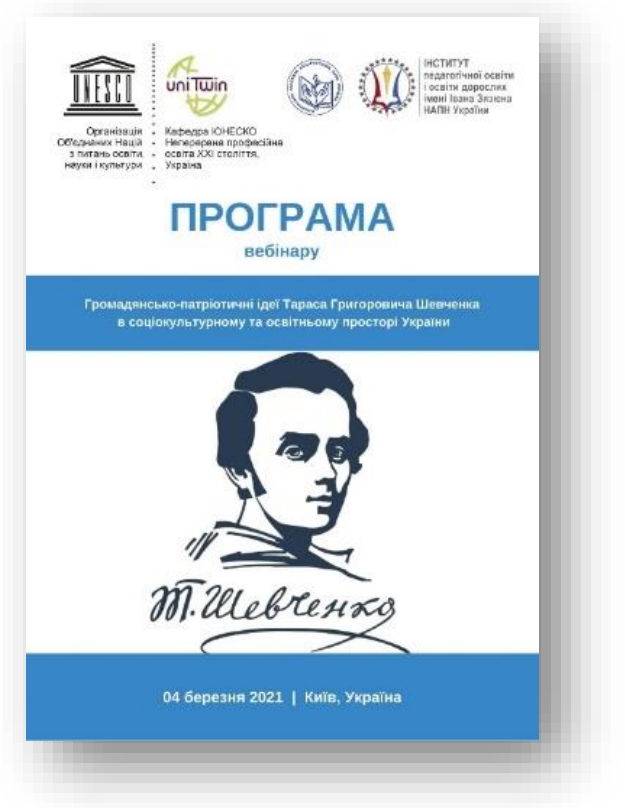

On March 4, 2021, the webinar «Civic and patriotic ideas of Taras Shevchenko in the socio-cultural and educational space of Ukraine 2021» was held. The webinar was organized by the UNESCO Chair on Lifelong Professional Education in the XXI Century and Ivan Ziaziun Institute of Pedagogical Education and Adult Education of NAPS of Ukraine. More than 80 people took part in the webinar, including public figures, artists, art critics, scientists, university professors, teachers of secondary schools, coaches, students, post graduates. The participants of the webinar were various institutions of general secondary education, vocational education, professional higher education, higher education, NGOs, museums and reserves of Ukraine, namely:

- Taras Shevchenko Institute of Literature of the National Academy of Sciences of Ukraine;

- Taras Shevchenko All-Ukrainian Society «Prosvita»;
- Pavlo Tychyna Uman State Pedagogical University;

- V.G. Korolenko Poltava National Pedagogical University;

- Vasyl Stefanyk Precarpathian National University;

- Yurii Fedkovych Chernivtsi National University;

- Drahomanov National Pedagogical University;

- V.O. Sukhomlinskyi State Scientific and Pedagogical Library;

- Anton Makarenko Kyiv Professional and Pedagogical College;

- Berdychiv Pedagogical Professional College of Zhytomyr Regional Council;

- Institute of Postgraduate Pedagogical Education of Chernivtsi Region; Kyiv;

- Gymnasium-boarding school № 13 in

- Leliukhiv Secondary School of I-II Grades of Novosanzhary Territorial Community of Poltava Region;

- $\quad$ Kyiv-Pechersk Lavra National Reserve.

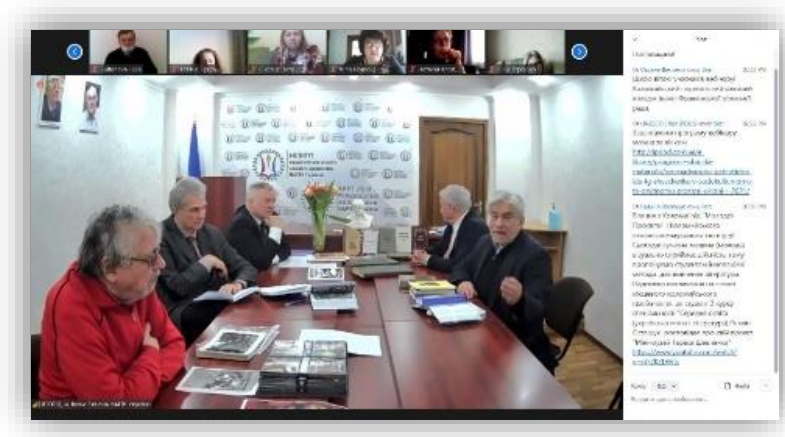

Fig. 2. Speakers of «Civic and patriotic ideas of Taras Shevchenko in the sociocultural and educational space of Ukraine 2021» webinar

Speakers of the webinar were well-known Ukrainian statesmen and public figures, diplomats, museum critics, local historians, folk artists of Ukraine, scientists, namely:

Movchan Pavlo - Chairman of Taras Shevchenko All-Ukrainian Society «Prosvita» (report - TARAS SHEVCHENKO IN THE CINEMA ART)

- Halchenko Serhii - PhD, Deputy Director of Taras Shevchenko Institute of Literature of the National Academy of Sciences of Ukraine (report - MANUSCRIPTS AND PRINTED PUBLICATIONS OF TARAS SHEVCHENKO) 
- Likhovyi Ihor - Ukrainian statesman and public figure, diplomat, museologist, local historian, culturologist, Minister of Culture and Tourism of Ukraine (2005-2006) (report - SACRED TARAS SHEVCHENKO)

- Haidamaka Anatolii - Honored Artist of Ukraine, Member of Ukraine National Academy of Arts, monumentalist (report - MUSEUM AS A IMAGE OF TARAS SHEVCHENKO)

- Franchuk Valerii - Honored Artist of Ukraine (report - KOBZAR of Taras Shevchenko IN THE WORKS OF VALERII FRANCHUK)

- Filipchuk Heorhii - Doctor of Sciences, Professor, Full Member (Academician) of the National Academy of Educational Sciences of Ukraine (report - TARAS SHEVCHENKO'S PEDAGOGICAL IDEALS AND THE PRESENT)

The Program of «Civic and patriotic ideas of Taras Shevchenko in the socio-cultural and educational space of Ukraine - 2021» webinar can be download by the link https://cutt.ly/EUECK4Y

MUSEUM PEDAGOGY - PROBLEMS, NOWADAYS, PROSPECTS. Innovative experience of working with children, youth and adults in the field of museum pedagogy and museum affairs was the subject of discussion of the participants at the IX scientific-practical conference «Museum pedagogy - problems, nowadays, prospects». The event was held on October 78, 2021 on the basis of the National Historical and Cultural Reserve «Kiev-Pechersk Lavra» in online and offline formats.

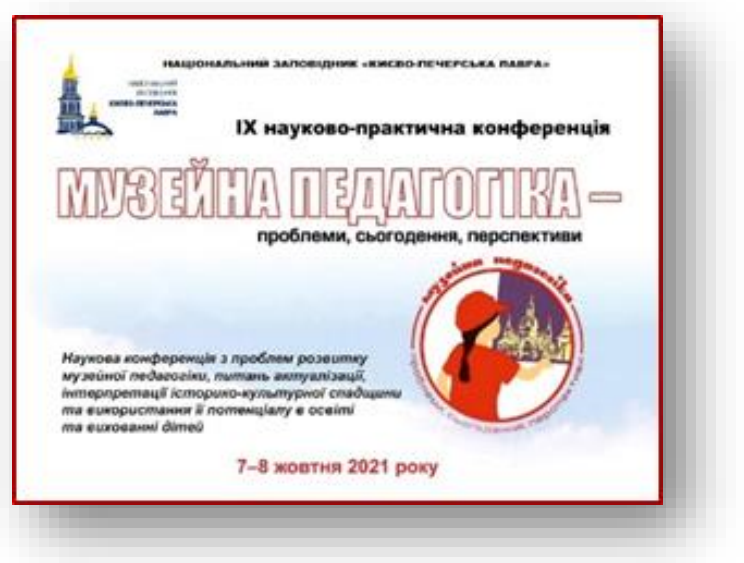

Initiators and organizers of the event UNESCO Chair on Lifelong Professional Education in the XXI Century; Kyiv-Pechersk Lavra National Reserve; Ivan Ziaziun Institute of Pedagogical Education and Adult Education of the National Academy of Educational Sciences of Ukraine; Research and Training Laboratory of Museum Pedagogy at Lviv Ivan Franko National University.

More than 50 participants of the event had the opportunity to see that the leading museums in Ukraine and abroad are important centers of education, upbringing and human development, as they provide access to national cultural and natural heritage to citizens of different ages and social categories. This is a scientific conference on the development of museum pedagogy, issues of actualization, interpretation of historical and cultural heritage and the use of its potential in education and upbringing of children.

The issues of reports revealed the following aspects: museum culture for quality education; museum psychology in the system of communication with visitors; how to present works of art for the visually impaired; use of the basic principles of museum pedagogy in the New Ukrainian School; visually in museum pedagogy; the influence of exhibits on the expansion of the museum audience; the role of museums in the cultural and educational activities of preschool education, etc.

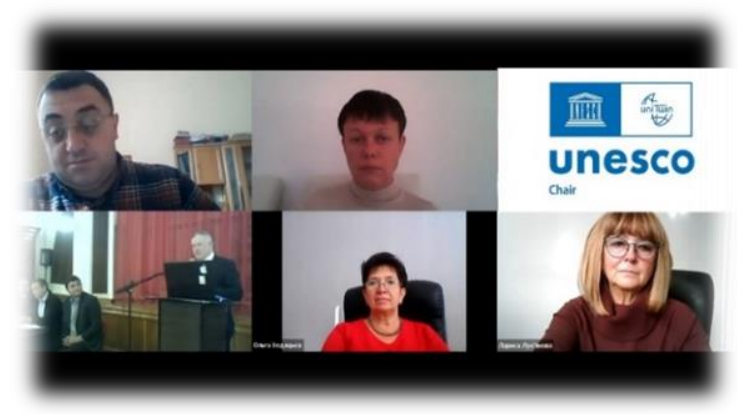

Fig. 3. Participans of «Museum pedagogy problems, nowadays, prospects - 2021»

Conference

The idea of the conference is the development of interaction between the museum and the educational institution (school, college, institute, university and even kindergarten). Practically all action and interaction are aimed at education, improvement, development of human competencies, in accordance with the strategies, cultural traditions and political objectives implemented in each state.

The Program of «Museum pedagogy - problems, nowadays, prospects - 2021» conference can be download by the link https://cutt.ly/pUENo5R 
XIX INTERNATIONAL ARTISTIC AND PEDAGOGICAL READINGS IN MEMORY OF PROFESSOR OKSANA RUDNYTSKA

On December 1, 2021, the XIX International Art and Pedagogical Readings in Memory of Professor Oksana Rudnytska «Lifelong Pedagogical Education in the XXI Century: experience, innovations, trends» was held. The mission of the event is to promote openness of science and educational practice, partnership of educational institutions and scientific institutions in reforming art and pedagogical education, honoring the memory of significant figures for Ukrainian education, great in producing innovative research ideas of individuals.

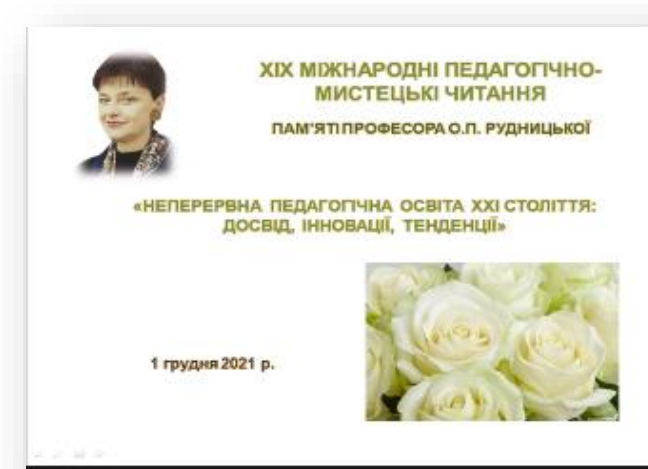

The initiators of the annual event were: UNESCO Chair on Lifelong Professional Education in the XXI Century and Ivan Ziaziun Institute of Pedagogical Education and Adult Education of NAES of Ukraine. The partners of the event were the Ukrainian Association of Adult Education, Stefan Cel Mare University of Suceava. The event was attended by more than 300 participants - scientists, educators from different regions of Ukraine and abroad:

- Pavlo Tychyna Uman State Pedagogical University;

- A.S. Makarenko Sumy State Pedagogical University;

- Drahomanov National Pedagogical University;

- Mykhailo Kotsiubynskyi Vinnytsia State Pedagogical University;

- Yurii Fedkovych Chernivtsi National University;

- Kherson State University,

- Anton Makarenko Kyiv Professional and Pedagogical College.

The plenary session was traditionally opened by the performance of the chamber orchestra of the Anatolii Avdievskyi Faculty of
Arts of the Drahomanov National Pedagogical University (artistic director - Honored Artist of Ukraine, Doctor of Sciences, Professor Vasyl Fedoryshyn; conductor - Savchenko Halyna).

In the context of defining modern issues of art education, Vice-Rector of Stefan Cel Mare University (Suceava, Romania), Professor Stefan Puric noted the need for further constructive cooperation between Ukrainian and Romanian research institutions. Heorhii Filipchuk (Doctor of Sciences, Professor) designed the need to update the content of modern education taking into account the potential of Ukrainian sciences, use the existing cultural heritage of Ukraine, produced by famous Ukrainian scientists, teachers and artists.

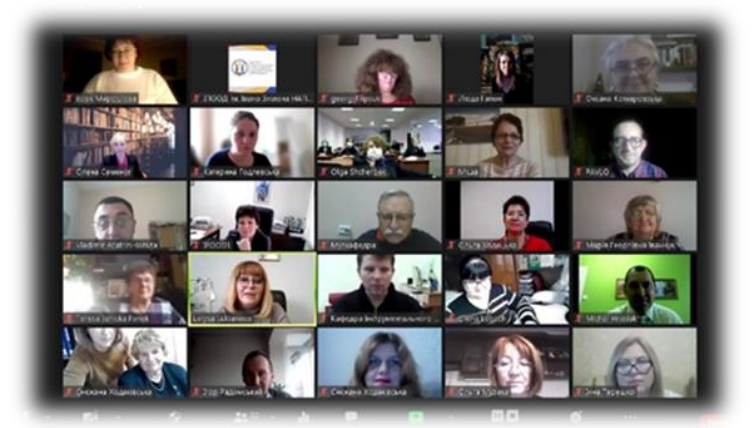

Fig. 4. Participants of «XIX International Art and Pedagogical Readings in Memory of

Professor Oksana Rudnytska - 2021» Readings

Reports of famous Ukrainian and foreign researchers highlighted important issues of modern lifelong education: theoretical and practical aspects of assessing student achievement (report by Hnatiuk Michal, Institute of Law, Psychology and Innovative Education of Lviv Polytechnic National University); interdepartmental relations of the educational process in the formation of creative personality of students in the faculties of arts (report by Fedoryshyn Vasyl, Dean of Anatolii Avdievskyi Faculty of Arts, Drahomanov National Pedagogical University); artistic cognition and its organization in the process of teaching art in general secondary education (report by Komarovska Oksana, the Head of the Laboratory of Aesthetic Education and Art Education, Institute of Educational Problems, National Academy of Educational Sciences of Ukraine); the importance of the basic curriculum in the work of primary school teachers in the education system (report by Teresa Yanitska-Panek, Professor of the Stefan Batory State Institution of Higher Education in Skierniewice (Ski- 
erniewice, Republic of Poland); humanistic orientation as a priority characteristic of the modern music art teacher activity (report by Horbenko Serhii, professor of Anatolii Avdievskyi Faculty of Arts, Drahomanov National Pedagogical University); online projects of the Pedagogical Museum of Ukraine: topics, content, implementation (report by Mikhno Oleksandr, Director of the Pedagogical Museum); certificate program «Organization and directing of cultural and artistic projects» in the educational process of Kherson State University (report by Lymarenko Lydia, Head of the Department of Cultural Studies, Kherson State University); formation of research skills as a step towards self-realization in nonformal education (report by Khodatska Olha, teacher of Boarding school №13 in Kyiv).

Liudmyla Shtoma (the Head of the Scientific Library of the Ivan Ziaziun Institute of Pedagogical Education and Adult Education of the National Academy of Educational Sciences of Ukraine) presented an exhibition of scientific works of Professor Oksana Rudnytska and new scientific, pedagogical and artistic publications.

The Program of «XIX International Art and Pedagogical Readings in Memory of Professor Oksana Rudnytska - 2021» conference can be download by the link https://cutt.ly/EUE0zqL

PSYCHOLOGICAL SUPPORT OF THE ELDERLY IN PANDEMIC PERIOD.

On November 29, 2021, the All-Ukrainian scientific-practical conference with international participation «Psychological Support of the Elderly in Pandemic Period» was held within the project «Psychological support of the elderly in pandemic period» by the grant support of National Research Fund of Ukraine. The main co-organizer of the conference was UNESCO Chair on Lifelong Professional Education in the XXI Century.

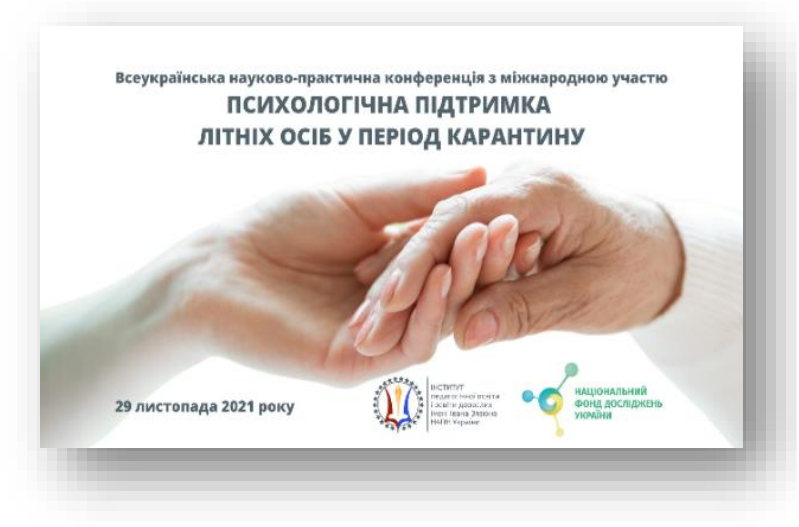

The conference was attended by over 100 participants not only from different regions of Ukraine but also abroad.

- 16 cities of Ukraine: Kherson, Poltava, Melitopol, Kyiv, Ivano-Frankivsk, Myrhorod, Cherkasy, Ternopil, Vinnytsia, Rivne, Berdiansk, Putivl, Mykolaiv, Kharkiv, Drohobych, Chernivtsi.

15 regions of Ukraine: Vinnytsia, Zaporizhia, Ivano-Frankivsk, Kyiv, Lviv, Mykolaiv, Poltava, Rivne, Sumy, Ternopil, Kharkiv, Kherson, Khmelnytsky, Cherkasy, Chernivtsi regions.

- 2 foreign cities - Warsaw, Krakow (Republic of Poland).

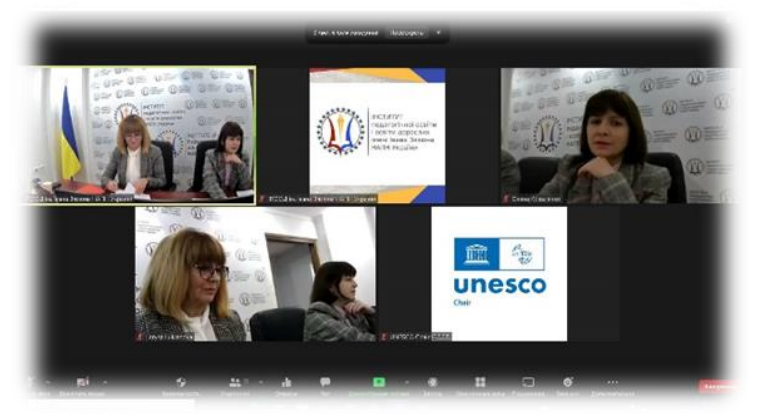

Fig. 5. Moderators of «Psychological support for the elderly in pandemic period» conference (O. Kovalenko, L. Lukianova)

Welcoming remarks were made by: Olha Polotska, Executive Director of the National Research Found of Ukraine; Vasyl Kremen, President of the National Academy of Educational Sciences of Ukraine; Norbert Pikula, Director of the Institute of Social Affairs, Krakow Pedagogical University (Republic of Poland); Oleksii Nestulia, Rector of the Poltava University of Economics and Trade

The participants of the plenary session made the following reports:

- OLD PEOPLE DURING QUARANTINE: PROBLEMS OF PSYCHOLOGICAL SUPPORT (Speaker - Kovalenko Olena, the Head of the Project);

- DZIAŁANIA WSPIERAJĄCE AKTYWNOŚĆ SENIORÓW W CZASIE PANDEMII (Speaker Norber Pikula, Director of the Institute of Social Affairs, Krakow Pedagogical University);

- IDEAL MODEL OF AGE AS A RESULT OF PERSONAL LIFE (Speaker - Pomytkin Eduard, Ivan Ziaziun Institute of Pedagogical Education and Adult Education);

- PRIORITY OF CULTURAL VALUE ORIENTATIONS OF ELDERLY PEOPLE (Speaker - 
Spivak Liubov, Drahomanov National Pedagogical University);

- ETECHNOLOGIES OF ELDERLY SUP-

PORT DURING QUARANTINE: EXPERIENCE OF UNIVERSITY OF THIRD AGE IN POLTAVA (Speaker - Oleksii Nestulia, Rector of Poltava University of Economics and Trade);

- MIGD-DIMENSIONAL QUESTIONNAIRE OF REAL, DESIRABLE AND FANTASTIC TIMES BUDGETS AS A MEANS OF PSYCHODIAGNOSTIC SUPPORT FOR THE ELDERLY'S LIFE (Speaker - Volodymyr Morhun, V.G. Korolenko Poltava National Pedagogical University);

- EDUCATIONAL ACTIVITY OF THE ELDERLY AS A FACTOR OF IDENTIFIED REGULATION AND PSYCHOLOGICAL SUPPORT IN QUARANTINE (Speaker - Lukianova Larysa, Director of Ivan Ziaziun Institute of Pedagogical Education and Adult Education).

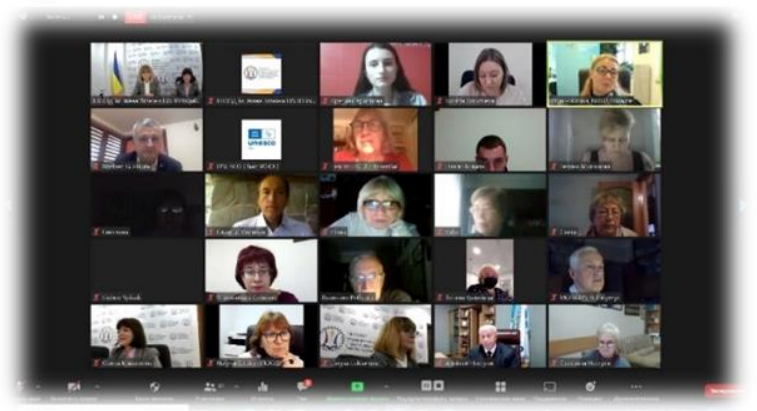

Fig. 6. Participants of «Psychological support for the elderly in pandemic period» conference

The discussion platform of the conference participants started in the afternoon. The main issues discussed at the conference, such as: Improving the emotional literacy of social workers as a guarantee of maintaining their psychological health under stress conditions (COVID-19); Psychological features of personality fear manifestation in elderly during quarantine; Self-realization of elderly during quarantine; Features of experience of loneliness in elderly; Foreign experience (on the example of China) of social work on provision of services to the elderly in quarantine; Health and recreational motor activity in improving the elderly quality life.

The COVID-19 pandemic has been a serious test for all mankind. Prolonged quarantine has affected the lives of our citizens and changed the information field for many of them. As a result, quarantine and self-isolation has become a special test for the elderly. Due to the limitations caused by this situation, they find themselves in difficult life circumstances, they can dramatically deteriorate their well-being and relationships with others, change attitudes towards themselves and the world, as well as the way of understanding the experience.

That is why the goal of the project was to promote the development of an elderly person who is in difficult life circumstances due to quarantine restrictions. This involves helping people of this age to overcome the difficulties associated with these limitations through the organization of their daily lives. The essence of the latter is to involve the elderly in various activities, in teaching them to influence their relationships and experiences.

The research within the Project is applied, it provided for the creation and implementation of specific products for psychological support of the elderly, for example: recommendations in the form of brochures and booklets, videos, webinars, radio programs, textbooks, and for those who provide services for the elderly (social and medical workers, drivers, salespeople, rehabilitation specialists, etc.). Also developed a special program of the workshop «Effective communication with the elderly and maintaining their own psychological health under stress». Almost 295 offline participants from Kyiv, Lviv, Poltava, Vinnytsia and 100 online participants from 10 regions of Ukraine (Kyiv, Ivano-Frankivsk, Kharkiv, Poltava, Vinnytsia, Zaporizhia, Mykolaiv, Lviv, Khmelnytsky, Donetsk) took part in such workshops.

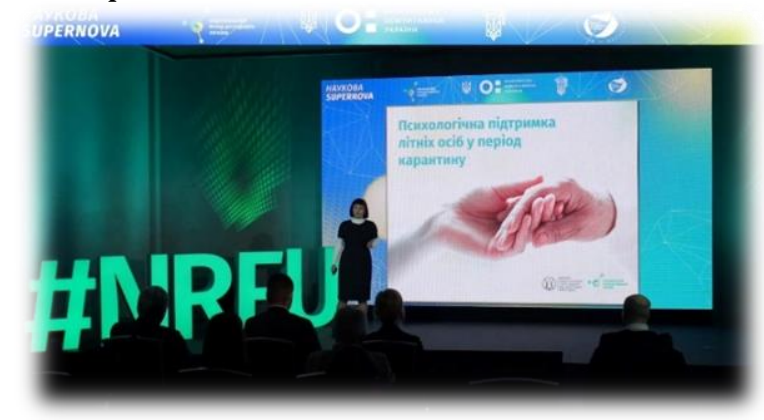

Fig. 7. Olena Kovalenko. «Scientific SuperNova»

On December 20, 2021, was held «Scientific SuperNova» - a communication event conducted by the National Research Found of Ukraine with the informational support of the Council of Young Scientists of the Ministry of Education and Science of Ukraine. This is a mass event at the state level on the activities of the best research projects in Ukraine. At the event «Scientific SuperNova» of the 77 projects of the winners in the competition «Science for Human Security and Society» with the 
grant support of the National Research Found of Ukraine was presented 8 best, including the project «Psychological support for the elderly in pandemic period». This project was implemented in 2020-2021 by the researchers of Ivan Ziaziun Institute of Pedagogical Education and Adult Education of NAES of Ukraine and members of UNESCO Chair on Lifelong Professional Education in the XXI Century.

The online broadcast was on YouTube channel of the National Research Found of Ukraine https://youtu.be/ SJo-XIVFWM

All videos of the project are posted on YouTube channel «Age of the Chosen» https://cutt.ly/eUEhvTc
You can find out news and about the project activities on the official pages in social networks:

https://www.facebook.com/project.ipood

You can download the project materials in the E-library of the Institute at the link:

https://cutt.ly/MUEhj3k

Conclusions. UNESCO Chair on Lifelong Professional Education in the XXI Century will continue carry out the organizational and cultural-educational activity, research and scientific activity, project activity, edition activity, digital information activity according to the aim of the Chair is to conduct researches on the problems of lifelong and pedagogical education, and the main tasks of the Chair.

\section{REFERENCES}

Avsheniuk, N., \& Bidyuk, N. (2021). Development of comparative professional pedagogy in the context of globalization and integration processes. Herald of the National Academy of Educational Sciences of Ukraine, 3(2). https://doi.org/10.37472/2707-305X-2021-3-2-17-14

Civic and patriotic ideas of Taras Shevchenko in the socio-cultural and educational space of Ukraine. (2021). Official website of Ivan Ziaziun Institute of Pedagogical Education and Adult Education of NAES of Ukraine. URL: https://cutt.ly/AUECFr4

Mother Language and Multilingual Education in the Context of Sustainable Development. (2021). Official website of Ivan Ziaziun Institute of Pedagogical Education and Adult Education of NAES of Ukraine. URL: https://cutt.ly/qUEHFID

Museum pedagogy - problems, nowadays, prospects. (2021). Official website of Ivan Ziaziun Institute of Pedagogical Education and Adult Education of NAES of Ukraine. URL: https://cutt.ly/SUENgTE

Psychological Support of the Elderly in Pandemic Period. (2021). Official website of Ivan Ziaziun Institute of Pedagogical Education and Adult Education of NAES of Ukraine. URL: https://cutt.ly/ZUE5Djk

Scientific SuperNova. (2021). Official website of Ivan Ziaziun Institute of Pedagogical Education and Adult Education of NAES of Ukraine. URL: https://cutt.ly/RUE5XXe

Sotska, H. (2020). UNESCO Chair on Lifelong Professional Education in the XXI Century of the NAES of Ukraine: Strategic Directions of Development. UNESCO Chair Journal Lifelong Professional Education in the XXI Century, (1), 8-11. https://doi.org/10.35387/ucj.1(1).2020.8-11

Vovk, M., \& Kotun, K. (2021). Development of mother language and multilingual education in ukraine: Experience of celebrating the International Mother Language Day by the UNESCO Chair on Lifelong Professional Education in the XXI Century of NAES of Ukraine. Herald of the National Academy of Educational Sciences of Ukraine, 3(1). https://doi.org/10.37472/2707-305X-2021-3-1-3-3

XIX International Art and Pedagogical Readings in Memory of Professor Oksana Rudnytska. (2021). Official website of Ivan Ziaziun Institute of Pedagogical Education and Adult Education of NAES of Ukraine. URL: https://cutt.ly/UUE0T0q

Ніна Гомеля, кандидат педагогічних наук, викладач-методист Київського професійнопедагогічного фахового коледжу імені Антона Макаренка, член Кафедри ЮНЕСКО «Неперервна професійна освіта XXI століття».

Nina Homelia, PhD in Pedagogy, teacher-methodologist of Anton Makarenko Kyiv Professional and Pedagogical Specialize College, member of UNESCO Chair on Lifelong Professional Education in the XXI Century.

E-mail: enes63@ukr.net ORCID ID 0000-0002-0638-5138 